\title{
Korea's Construction Business Informatization Overview and Future Plans
}

\author{
MyoungBae Seo \\ ICT Convergence and Integration Research Division \\ Korea Institute of Construction Technology \\ Goyang-Si, Gyeonggi-Do, Republic of Korea \\ smb@kict.re.kr
}

\begin{abstract}
South Korea's construction industry won orders worth USD 58 billion in 2011, and as such, it has achieved a remarkable growth. However, despite such an impressive quantitative growth, value-added quality growth has been very slow. Thus, the Ministry of Land, Transport and Marine Affairs (MLTM) is pushing ahead with the construction informatization initiative (Construction Continuous Acquisition \& Life-cycle Support - CALS) in order to systematically manage a wide range of construction information by stage and to enhance the efficiency of construction costs. This study aims to review the country's construction CALS to explore a construction development direction.
\end{abstract}

Keywords-Construction CALS, project management, land acquisition compensation, facility maintenacne, construction approval, and construction standards

\section{Introduction}

South Korea's construction industry has contributed to the country's economic growth and the people's housing stabilization through the building of SOC and the construction of housing. In this process, the construction investment amount and the value of earned construction orders have remarkably grown. The value of earned overseas construction orders reached USD 58 billion in 2011, and as such, large constructors are actively winning overseas construction orders. Notably, the MLTM is setting a goal of winning overseas construction orders worth USD 70 billion in 2012 by driving ahead with overseas construction initiatives and penetrating the Middle East and Asia construction markets where large-scale orders are expected. The government is preparing across-the-board support measures encompassing finances, technologies and diplomacy in order to achieve the 2012 goal. However, despite this impressive quantitative growth, due to a lack of engineering technology competitiveness, and not much transparent management, the country's construction industry is backward and has yet to achieve value-added quality development compared with that of developed countries.[1]

\author{
NamGon Kim \\ ICT Convergence and Integration Research Division \\ Korea Institute of Construction Technology \\ Goyang-si, Gyeonggi-do, Republic of Korea \\ ngkkim@kict.re.kr
}

Thus, the MLTM has formulated national informatization strategies to improve the construction industry's efficiency and advance its knowledge and informatization to create value-added construction businesses and bolster the industry's competitiveness. These efforts have improved diverse knowledge and informatization systems and services for the general public. Notably, in order to cope proactively to changing domestic and international environments and to strengthen the transparency and efficiency of construction project management through informatization, the government formulated the master plan for construction CALS in 1998 and has since implemented the construction informatization system. This study thus aims to review the country's construction business informatization overview and future development direction based on the construction CALS.

\section{Background to CALS Introudction and Implementation}

The construction business knowledge and informationzation systems were needed in order to improve the construction business efficiency and to create value-added construction businesses. An informatization strategy was formulated to enable clients and constructors to electronically exchange and share the production information of the entire construction business process encompassing design, construction work and maintenance. The outcome of the strategy is construction CALS.

In a bid to facilitate the informatization of construction work process and to effectively use the results of such efforts, the South Korean government formulates and implements a five-year master plan every five years.[2] The current construction CALS is stage 3 , and supports the strengthening of linkage with diverse institutes and national policies.

TABLE 1. Goals of Construction CALS by Stage

\begin{tabular}{c|c|c}
\hline Stage 1 & Stage 2 & Stage 3 \\
\hline \hline $\begin{array}{c}\text { Build clients' } \\
\text { infrastructures } \\
(1998-2002)\end{array}$ & $\begin{array}{c}\text { Computerize work } \\
\text { process } \\
(2003-2007)\end{array}$ & $\begin{array}{c}\text { Achieve advanced co- } \\
\text { work and integration } \\
(2008-2012)\end{array}$ \\
\hline $\begin{array}{c}\text { Computerize single-unit } \\
\text { works }\end{array}$ & $\begin{array}{c}\text { Build institutes } \\
\text { systems }\end{array}$ & $\begin{array}{c}\text { Support linkage } \\
\text { integration and policies }\end{array}$ \\
\hline
\end{tabular}




\section{Implementation of Construction CALS}

In order to exchange and share information on the whole construction business process, six construction CALS systems, including construction business management, construction approval, land acquisition compensation, facility maintenance, construction CALS portal, and harbor construction information integration system are now being operated. Currently, these are applied to some 1,000 projects in roads, rivers and harbors. They are outlined as follows.[3]

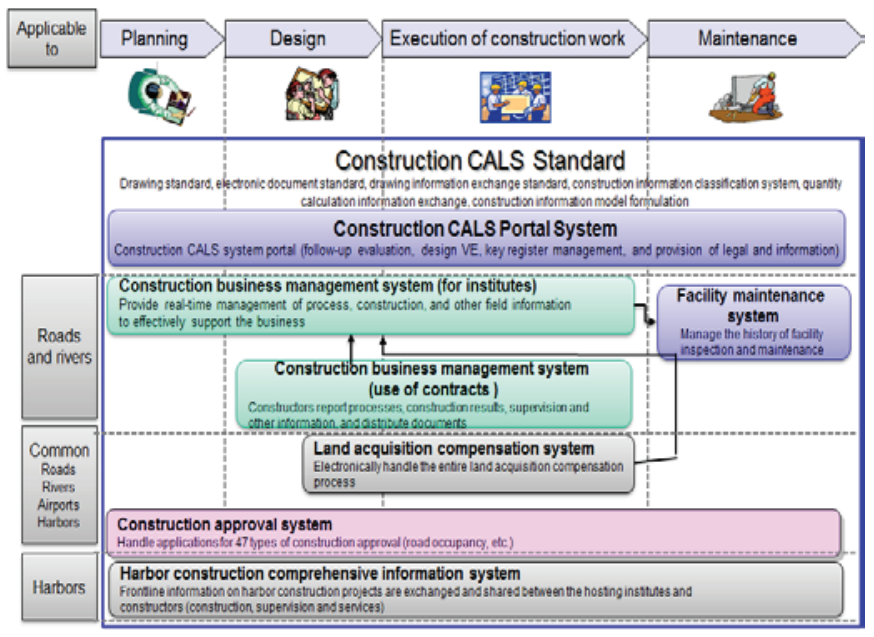

Figure 2. Six Types of Construction CALS Systems

Along with the systems, six types of standards are being implemented to exchange and share overall construction business data. They include electronic drawings, drawing information exchange, electronic documents, construction information classification system, devising of construction information models and common delivery criteria, and digital quantity calculation exchange standard. These standards are being utilized across the construction industry, and efforts are being made to establish some of them as international standards.[4]

\section{Construction CALS Development Direction}

The construction CALS should continue its development efforts to reduce the construction business costs, to improve the efficiency based on informatization strategies, and to meet the rapidly changing social needs. Thus, this study formulated the vision and goal of the construction CALS aimed at realizing the informatization of construction businesses that create the national wealth creation as a new growth engine.

To achieve this vision and goal, five major strategies were determined. To effectively implement these strategies, detailed strategies will be devised. Five major strategies are outlined as follows.
(1) Support the lifecycle of construction business from planning to maintenance: Use systems in managing major construction business process data, expand workclassification system (WBS)-applicable projects, and link and integrate with the maintenance systems

(2) Facilitate the use of accumulated design and construction work information : Analyze and process accumulated information to give feedback to planning and design stages

(3) Link increased user convenience with IT: Adopt mobile, cloud computing, space information (GIS), and construction information model (BIM)

(4) SOC construction business portal service : Link with construction business systems for roads, harbors and railroads, run by the MLTM and institutes under its control, thus providing integrated services

(5) Use and promote the construction CALS : Organize construction business management systems to spread them as national standard models to local governments, etc., and to respond to additional standardization demand.

\section{Realize construction business informazation to create} national wealth as a new growth engine

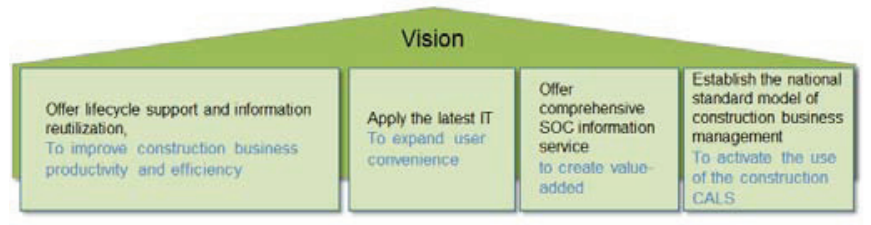

Figure 3. Expected Vision and Goal of Construction CALS

\section{Conclusion}

The application of construction CALS provides the following expected benefits. First, it is possible to reutilize the existing information, gather information speedily, cut the construction period and reduce the cost. It is possible to cut the construction period by $15 \% \sim 20 \%$ and a yearly project budget of KRW 177.7 billion. Second, it is possible to make speedy communications by sharing information across the construction business stages, and to cut user waiting time by $30 \% \sim 60 \%$. Third, it is possible to eliminate paper documents and effectively use spaces and to reduce document distribution costs. Also, it is possible to improve the public and private-sector construction work quality, to help eliminate poor construction works, and to strengthen the country's construction industry competitiveness.

The construction CALS will respond to the ever changing social needs, and continue to expand and develop so as to establish itself as a new growth engine in the construction category in South Korea. 


\section{ACKNOWELEDGMENT}

Part of this research was conducted as part of the MLTM's project to operate the CALS system and improve its functions. We would like to express our thanks to the MLTM.

\section{REFERENCES}

[1] Jin Gyeong-ho, Opportunities for the Improvement of Competitiveness and Efficiency of Construction Industry, NIIST's Role, Construction Technology Trends 2010, KICT, December 2010.

[2] MLTM, Third Master Plan for Construction CALS, December 2007.

[3] KICT, 2010 Construction CALS Operation and Function Improvement, MLTM, March 2010.

[4] KICT, 2010 Construction CALS Standard Construction and Operation, MLTM, March 2010. 